\title{
PERILAKU POLA KERETAKAN BENDA UJI KUBUS DAN SILINDER YANG TERKEKANG TERHADAP BEBAN MAKSIMUM MENGGUNAKAN METODE ELEMEN HINGGA
}

\author{
Fitriani Ridzeki, ST. MT. \\ Prodi Teknik Sipil, Fakultas Teknik, Universitas Islam Kalimantan MAB \\ Jl. Adhyaksa No. 2 Kayu Tangi Banjarmasin \\ E-mail: fitrianiridzeki@yahoo.com/HP.+62811504582
}

\begin{abstract}
ABSTRAK
Di Indonesia kerusakan bangunan yang cukup besar diakibatkan oleh aktivitas tektonik atau gempa bumi. Sebagian terjadi pada daerah lepas pantai dan daerah pemukiman bahkan kawasan perkantoran. Bangunan tingkat tinggi pada suatu struktur bangunan harus memiliki struktur yang kuat terhadap gaya gempa. Oleh karena itu diperlukan sebuah desain bangunan yang lebih memperhatikan tingkat kinerja bangunan yaitu desain penulangan dan sambungan dari keseluruhan struktur, yang bisa diperoleh dari pengujian kuat tekan beton benda uji untuk mewakili sebuah struktur. Pengujian kuat tekan beton menggunakan benda uji kubus dan silinder yang terkekang telah dilakukan menggunakan metode elemen hingga. Benda uji kubus $15 \mathrm{~cm} \times 15 \mathrm{~cm} \times 15 \mathrm{~cm}$ dan kubus $20 \mathrm{~cm} \times 20 \mathrm{~cm} \times 20$ jarak sengkang $5 \mathrm{~cm}$ dan silinder diameter $15 \mathrm{~cm}$ dan tinggi $30 \mathrm{~cm}$ yang terkekang dengan jarak sengkang 5 $\mathrm{cm}$ dan $10 \mathrm{~cm}$. penelitian yang dilakukan adalah pengujian kuat tekan beton pada benda uji kubus dan silinder yang diberi pengekangan untuk mendapatkan nilai beban maksimum, tegangan dan pola keretakan yang terjadi yang terjadi. Perilaku tegangan von misses dan pola keretakan yang terjadi dipengaruhi oleh mutu dari material baja untuk tulangan dan material beton. Semakin tinggi mutu beton maka nilai tegangan maksimum yang dicapai juga semakin besar. Jarak sengkang juga mempengaruhi nilai beban maksimum, semakin rapat jarak antar sengkang maka nilai beban maksimum semakin besar. Sedangkan pada benda uji silinder jarak sengkang dengan pengekangan persegi tidak mempengaruhi nilai beban maksimum.
\end{abstract}

Kata kunci: pola retak, benda uji, pengekangan

\section{ABSTRACT}

In Indonesia, significant damage to buildings is caused by tectonic activity or earthquakes. Some occur in offshore areas and residential areas and even office areas. High-rise buildings in a building structure must have a strong structure against earthquake forces. Therefore we need a building design that pays more attention to the level of building performance, namely the design of reinforcement and joints of the entire structure, which can be obtained from testing the compressive strength of the concrete of the test object to represent a structure. Testing of the compressive strength of concrete using confined cube and cylinder specimens has been carried out using the finite element method. The specimens were cube $15 \mathrm{~cm} \times 15 \mathrm{~cm} \times 15 \mathrm{~cm}$ and cube $20 \mathrm{~cm} \times 20 \mathrm{~cm} \times 20$ with a spacing of 
$5 \mathrm{~cm}$ and a cylinder with a diameter of $15 \mathrm{~cm}$ and a height of $30 \mathrm{~cm}$ which were restrained with a stirrup distance of $5 \mathrm{~cm}$ and $10 \mathrm{~cm}$. The research carried out is testing the compressive strength of concrete on cube and cylinder specimens that are given restraint to obtain the maximum load value, stress and crack pattern that occurs. Von misses stress behavior and crack patterns that occur are influenced by the quality of the steel material for reinforcement and concrete material. The higher the quality of the concrete, the greater the maximum stress value achieved. The stirrup distance also affects the maximum load value, the closer the distance between the bars, the greater the maximum load value. Whereas in cylinder specimens, the stirrup distance with square restraint does not affect the maximum load value.

Key words: crack pattern, specimen, confined

\section{PENDAHULUAN}

Di Indonesia kerusakan bangunan yang cukup besar diakibatkan oleh aktivitas tektonik atau gempa bumi. Sebagian terjadi pada daerah lepas pantai dan daerah pemukiman bahkan kawasan perkantoran. Gempa yang terjadi dikelompokkan menjadi 3 bagian, yaitu : gempa ringan, sedang, dan besar.

Bangunan tingkat tinggi pada suatu struktur bangunan harus memiliki struktur yang kuat terhadap gaya gempa. Struktur yang kuat yaitu struktur yang tidak akan rusak dan tidak terjadi keruntuhan terhadap gaya-gaya yang bekerja seperti gaya gempa, dengan perencanaan sesuai dengan daerah dan kondisi tanah pada wilayah yang akan di bangun bangunan tersebut. Keretakan awal pada dinding bata merupakan indikator awal akan terjadinya penurunan kekuatan struktur terhadap elemenelemen struktur seperti balok dan kolom, dan terus berlanjut sampai terjadinya keruntuhan bangunan (Tjitradi, 2018). Struktur bangunan yang buruk menjadi salah satu penyebab banyaknya rumah dan bangunan yang rusak saat terjadinya gempa.

Oleh karena itu diperlukan sebuah desain bangunan yang lebih memperhatikan tingkat kinerja bangunan yaitu desain penulangan dan sambungan dari keseluruhan struktur, yang bisa diperoleh dari pengujian kuat tekan beton benda uji untuk mewakili sebuah struktur. Tujuan penelitian ini adalah untuk mengetahui bagaimana pola retak dan tegangan yang terjadi pada benda yang diberi pengekangan (confinement). Standar benda uji yang digunakan pengujian kuat tekan adalah silinder dengan diameter $15 \mathrm{~cm}$ dan tinggi $30 \mathrm{~cm}$ yang dimodelkan dengan Software ANSYS.

Benda uji akan meningkat kekuatannya apabila dilakukan pengekangan. Pada umumnya pengekangan dilakukan menggunakan sengkang atau tulangan transversal. (Ridzeki, 2020). 


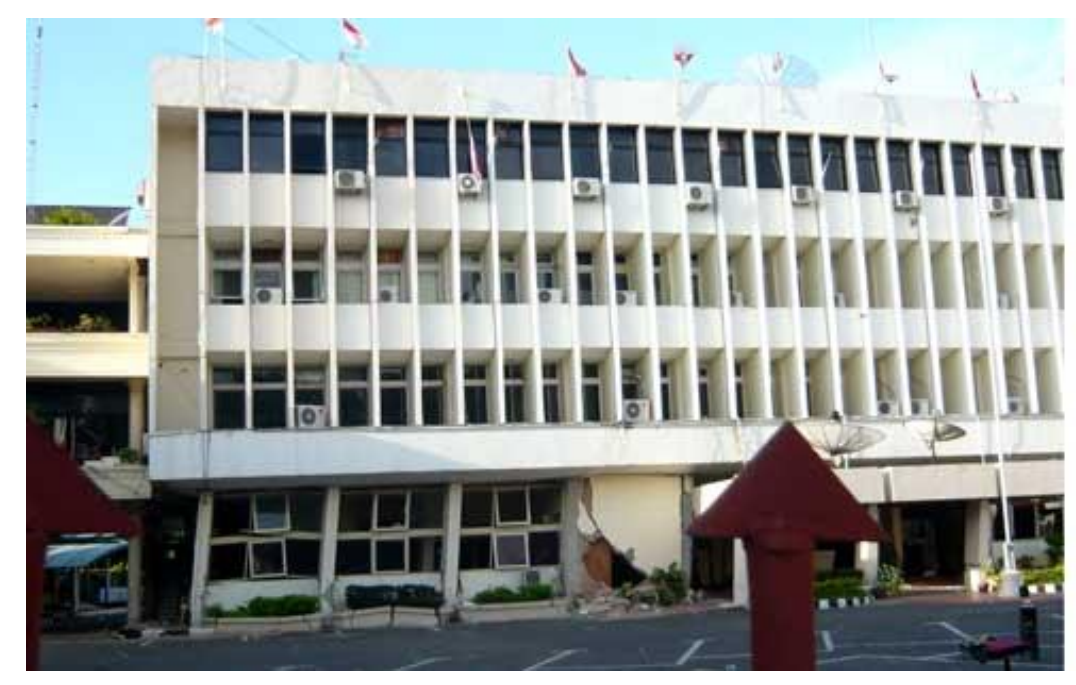

Gambar 1. Kantor DPU Padang Akibat Gempa Tahun 2009

\section{METODE PENELITIAN}

Metode penelitian yang digunakan adalah:

1) Melakukan studi literatur untuk mendalami materi yang berhubungan dengan penelitian, yang meliputi berbagai buku teks, jurnal ilmiah, peraturan dan Standar Nasional maupun Internasional.

2) Membuat pemodelan pada software ANSYS ED. 9 berdasarkan variasi bentuk, penulangan dan pengekangan.

3) Menganalisa hasil ANSYS berupa pola retak benda uji kubus dan silinder, beban maksimum, deformasi, dan tegangan yang terjadi;

4) Membuat kesimpulan hasil dari permodelan sesuai dengan tujuan.

Gambar 1 adalah model eksperimen yang digunakan sebagai pembanding. Nilai $f_{c}$, yang digunakan pada software ANSYS ED. 9.0 adalah hasil perhitungan yang kemudian divalidasikan dan diimplementasikan untuk penelitian ini. Mutu beton $\left(f_{c}{ }^{\prime}\right)$ yang digunakan pada validasi data (hasil uji eksperimental yang akan dicapai pada uji laboratorium).

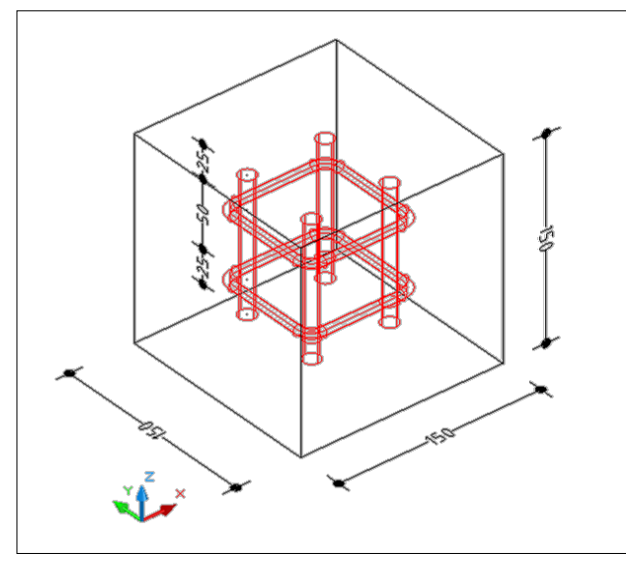

Gambar 2. Benda Uji Kubus $150 \mathrm{~mm} \times 150 \mathrm{~mm} \times 150 \mathrm{~mm}$ dengan Jarak Sengkang $50 \mathrm{~mm}$ 


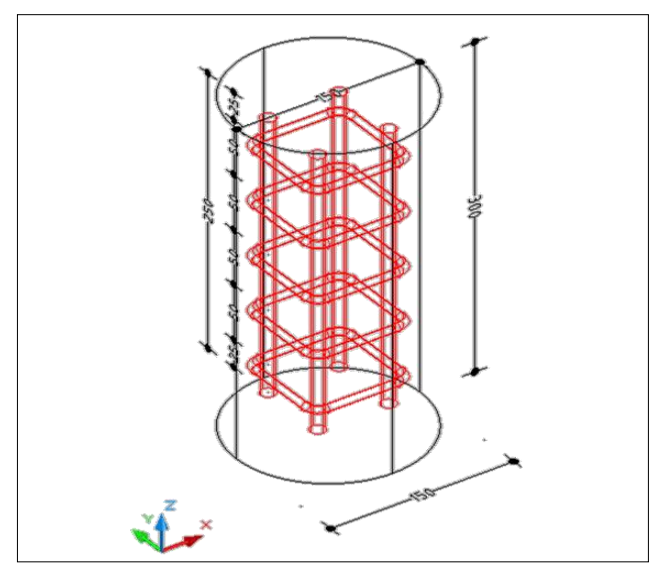

Gambar 3. Benda Uji Silinder Diameter $150 \mathrm{~mm}$ dan Tinggi $300 \mathrm{~mm}$ Jarak Sengkang $50 \mathrm{~mm}$

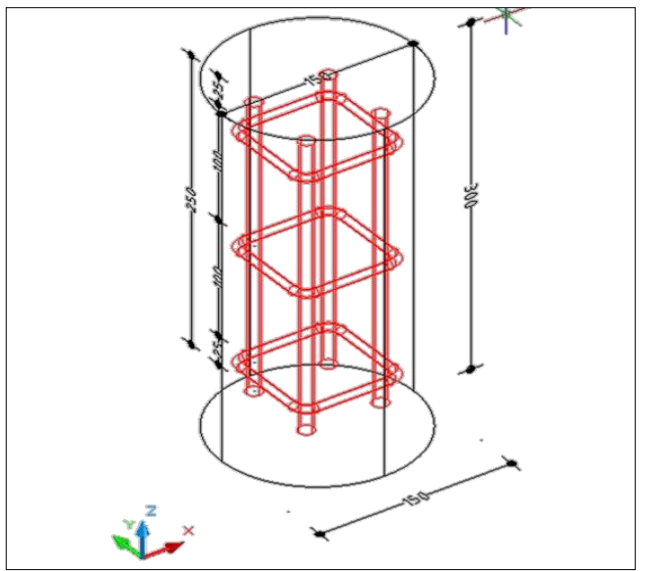

Gambar 4. Benda Uji Silinder Diameter $150 \mathrm{~mm}$ dan Tinggi $300 \mathrm{~mm}$ Jarak Sengkang $100 \mathrm{~mm}$

Penelitian ini adalah membuat model eksperimen dengan software ANSYS ED. 9.0 dengan data yang diinput dari hasil uji eksperimental laboratorium. Pemodelan spesimen beton kemudian dianalisis dan hasil analisisnya dibandingkan dengan hasil uji eksperimental tersebut. Apabila hasil sudah tervalidasi kemudian dilanjutkan dengan implementasi model dengan variasi bentuk kubus, penulangan dan pengekangan.

\section{HASIL DAN PEMBAHASAN}

Berdasarkan hasil uji numerik pemodelan elemen hingga menggunakan program ANSYS ED.9.0 diperoleh beban maksimum masing-masing benda uji pada kondisi mutu beton (fc') $20 \mathrm{MPa}, 25 \mathrm{MPa}, 30 \mathrm{MPa}$ dan bentuk kubus dimensi $150 \mathrm{~mm} \times$ $150 \mathrm{~mm}, 200 \mathrm{~mm} \times 200 \mathrm{~mm}$ dan silinder diameter $150 \mathrm{~mm}$ tinggi $300 \mathrm{~mm}$ tak terkekang dan terkekang pada jarak sengkang vertikal $50 \mathrm{~mm}, 100 \mathrm{~mm}$ dan $200 \mathrm{~mm}$ seperti tercantum pada Tabel 1. 
Tabel 1. Nilai Beban, Deformasi, Tegangan dan Regangan pada Kondisi

Maksimum Hasil Pemodelan Spesimen Menggunakan ANSYS ED.9.0

\begin{tabular}{|c|l|c|c|c|c|}
\hline \multirow{2}{*}{ No } & \multirow{2}{*}{ Model } & \multicolumn{4}{|c|}{ Kondisi Maksimum } \\
\cline { 3 - 6 } & & $\boldsymbol{P}_{\mathbf{u}}(\mathbf{k N})$ & $\Delta_{\mathbf{u}}(\mathbf{m m})$ & $\boldsymbol{\sigma}_{\mathbf{u}}\left(\mathbf{N} / \mathbf{m m}^{2}\right)$ & $\boldsymbol{\varepsilon}_{\mathbf{u}}(\boldsymbol{\%})$ \\
\hline 1 & K150-0-20 & 288,85 & 0,12 & 12,84 & 0,95 \\
\hline 2 & K150-50-20 & 299,25 & 0,12 & 13,30 & 0,86 \\
\hline 3 & K200-0-20 & 438,37 & 0,16 & 10,96 & 1,24 \\
\hline 4 & K200-100-20 & 525,30 & 0,16 & 13,13 & 1,08 \\
\hline 5 & K200-50-20 & 550,49 & 0,35 & 13,76 & 2,47 \\
\hline 6 & S300-0-20 & 207,02 & 0,22 & 11,72 & 1,71 \\
\hline 7 & S300-200-20 & 229,72 & 0,22 & 13,01 & 1,58 \\
\hline 8 & S300-100-20 & 229,75 & 0,22 & 13,01 & 1,59 \\
\hline 9 & S300-50-20 & 232,19 & 0,22 & 13,15 & 1,61 \\
\hline
\end{tabular}

Dari Tabel 1 dapat dilihat pengaruh pengekangan dan luas pembebanan terhadap beban maksimum yang dapat ditahan model, dengan adanya terkekang bisa menambah ketahanan model terhadap pembebanan.

Tabel 2. Nilai Beban, Deformasi, Tegangan dan Regangan pada Kondisi

Maksimum Hasil Pemodelan Spesimen Menggunakan ANSYS ED.9.0

\begin{tabular}{|c|l|c|c|c|c|}
\hline \multirow{2}{*}{ No } & \multirow{2}{*}{ Model } & $\boldsymbol{P}_{\mathbf{u}(\mathbf{k N})}$ & $\Delta_{\mathbf{u}}(\mathbf{m m})$ & $\boldsymbol{\sigma}_{\mathbf{u}}\left(\mathbf{N} / \mathbf{m m}^{\mathbf{2}}\right)$ & \multirow{2}{*}{$\boldsymbol{\varepsilon}_{\mathbf{u}}(\boldsymbol{\%})$} \\
\cline { 3 - 6 } & & & & & \\
\hline 1 & K150-0-25 & 353,06 & 0,12 & 15,69 & 0,71 \\
\hline 2 & K150-50-25 & 388,90 & 0,13 & 17,28 & 0,72 \\
\hline 3 & K200-0-25 & 640,58 & 0,17 & 16,01 & 0,97 \\
\hline 4 & K200-100-25 & 668,88 & 0,17 & 16,72 & 0,93 \\
\hline 5 & K200-50-25 & 674,64 & 0,20 & 16,87 & 1,12 \\
\hline 6 & S300-0-25 & 264,37 & 0,23 & 14,97 & 1,42 \\
\hline 7 & S300-200-25 & 289,60 & 0,23 & 16,40 & 1,36 \\
\hline 8 & S300-100-25 & 289,60 & 0,23 & 16,40 & 1,36 \\
\hline 9 & S300-50-25 & 292,16 & 0,24 & 16,54 & 1,38 \\
\hline
\end{tabular}

Dari Tabel 2 dapat dilihat pengaruh pengekangan dan luas pembebanan terhadap beban maksimum yang dapat ditahan model, dengan adanya terkekang bisa menambah ketahanan model terhadap pembebanan. 
Tabel 3. Nilai Beban, Deformasi, Tegangan dan Regangan pada Kondisi Maksimum Hasil Pemodelan Spesimen Menggunakan ANSYS ED.9.0

\begin{tabular}{|c|l|c|c|c|c|}
\hline \multirow{2}{*}{ No } & \multirow{2}{*}{ Model } & $\boldsymbol{P}_{\mathbf{u}}(\mathbf{k N})$ & $\Delta_{\mathbf{u}}(\mathbf{m m})$ & $\boldsymbol{\sigma}_{\mathbf{u}}\left(\mathbf{N} / \mathbf{m m}^{\mathbf{2}}\right)$ & \multirow{2}{*}{$\boldsymbol{\varepsilon}_{\mathbf{u}}(\boldsymbol{\%})$} \\
\cline { 3 - 6 } & & & & & \\
\hline 1 & K150-0-30 & 430,45 & 0,16 & 19,13 & 0,59 \\
\hline 2 & K150-50-30 & 461,85 & 0,16 & 20,53 & 0,59 \\
\hline 3 & K200-0-30 & 760,62 & 0,17 & 19,02 & 0,79 \\
\hline 4 & K200-100-30 & 786,69 & 0,17 & 19,67 & 0,79 \\
\hline 5 & K200-50-30 & 817,34 & 0,17 & 20,43 & 0,83 \\
\hline 6 & S300-0-30 & 169,14 & 0,23 & 19,15 & 1,11 \\
\hline 7 & S300-200-30 & 175,91 & 0,24 & 19,92 & 1,14 \\
\hline 8 & S300-100-30 & 176,37 & 0,24 & 19,97 & 1,14 \\
\hline 9 & S300-50-30 & 178,07 & 0,24 & 20,16 & 1,10 \\
\hline
\end{tabular}

Dari Tabel 3 dapat dilihat pengaruh pengekangan dan luas pembebanan terhadap beban maksimum yang dapat ditahan model, dengan adanya terkekang bisa menambah ketahanan model terhadap pembebanan.

Perilaku kontur tegangan dan pola retak yang terjadi pada setiap model benda uji. Didapat dari hasil analisis metode elemen hingga menggunakan software ANSYS pada kondisi beban ultimit.

Pada Gambar 5, 6 dan 7 tegangan maksimum dan keretakan terjadi pada titik ujung atas dan bawah kubus. Kenaikan mutu beton sejajar dengan kenaikan beban maksimum yang terjadi

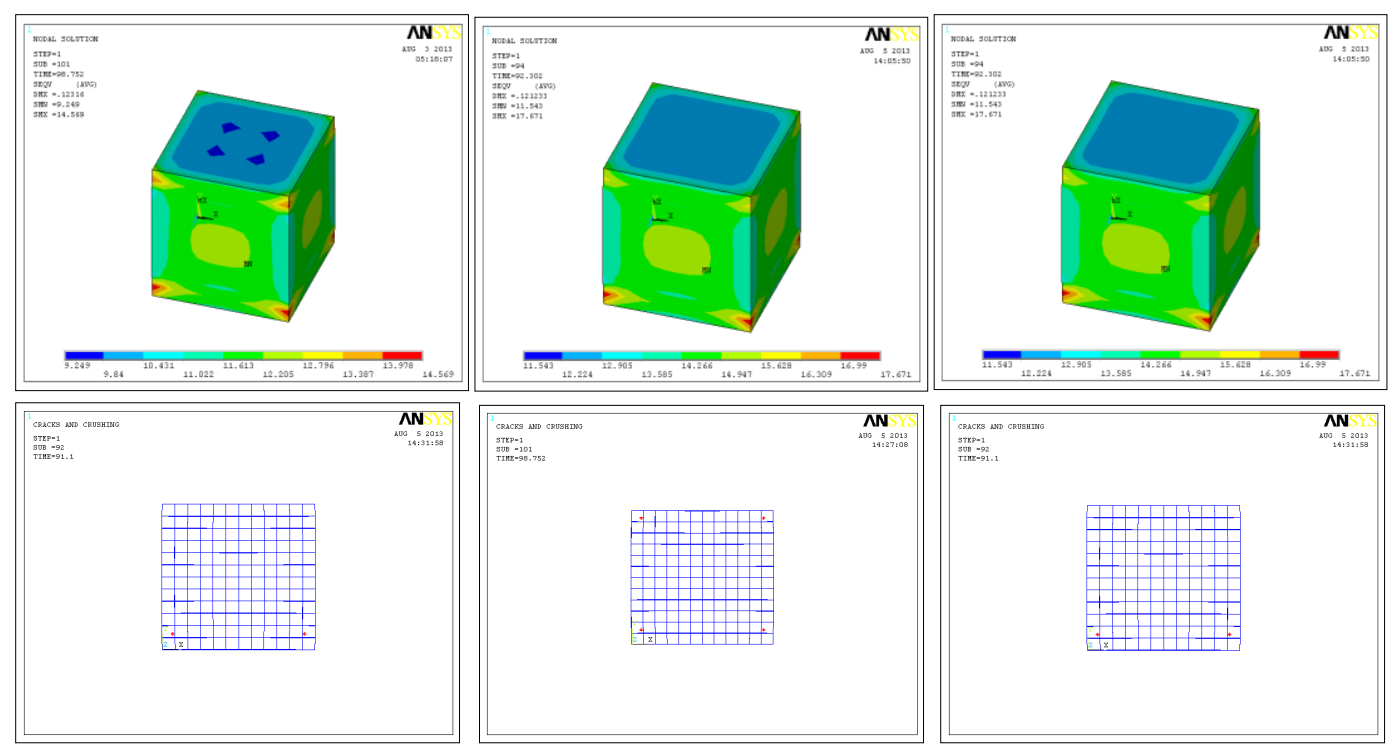

Gambar 5. Gambar Tegangan Von Misess dan Pola Retak Benda Uji Kubus Dimensi $150 \mathrm{~mm} \times 150 \mathrm{~mm}$ Tak Terkekang 
JURNAL KACAPURI

JURNAL KEILMUAN TEKNIK SIPIL

Volume 4 Nomor 1 Edisi Juni 2021

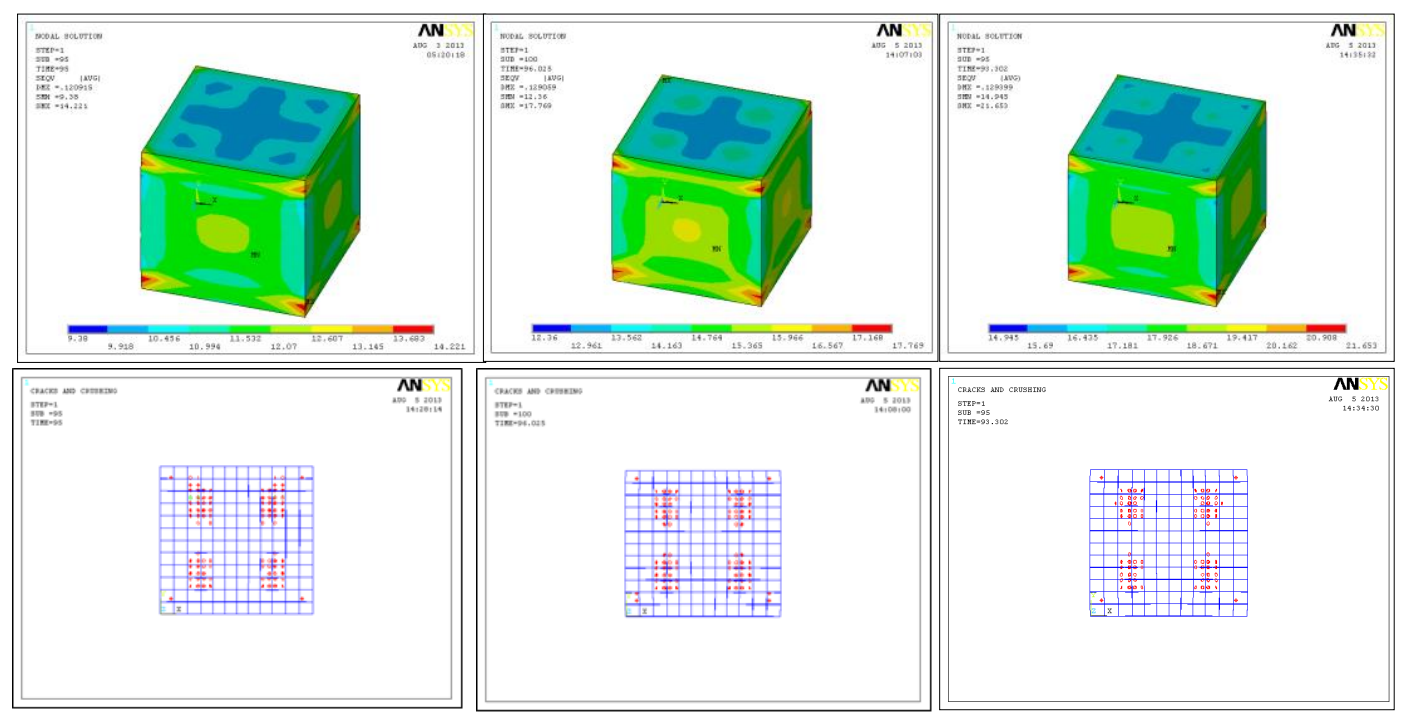

Gambar 6. Gambar Tegangan Von Misess dan Pola Retak Benda Uji Kubus

Dimensi $150 \mathrm{~mm} \times 150 \mathrm{~mm}$ yang Terkekang dengan $\mathrm{s}=50 \mathrm{~mm}$

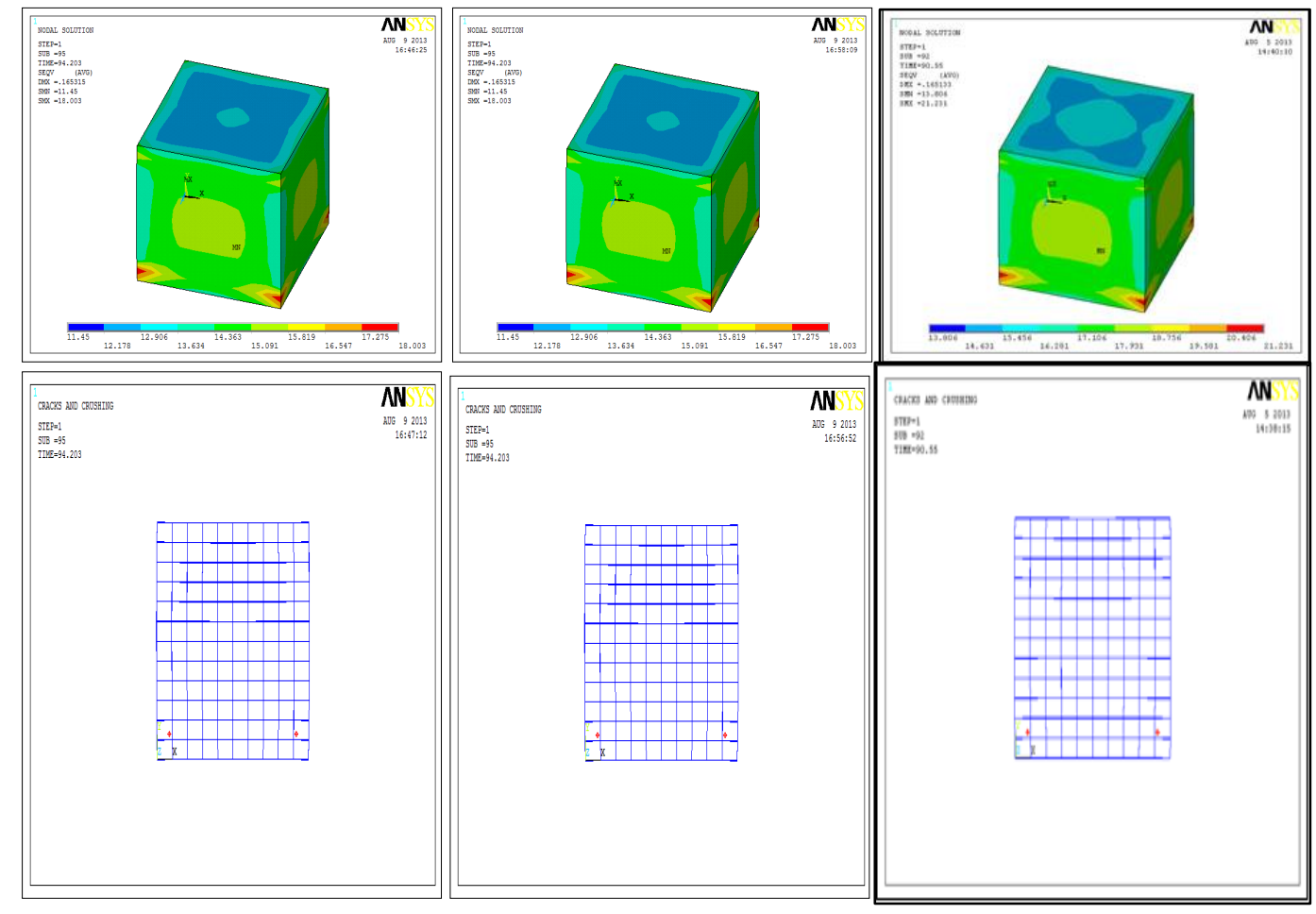

Gambar 7. Gambar Tegangan Von Misess dan Pola Retak Benda Uji Kubus Dimensi $200 \mathrm{~mm} \times 200 \mathrm{~mm}$ Tidak Terkekang 
Pada Gambar 8 dan 9 tegangan maksimum dan keretakan terjadi pada titik ujung atas dan bawah kubus dan daerah sekitar sengkang dan tulangan utama. Kenaikan mutu beton sejajar dengan kenaikan tegangan maksimum yang terjadi.

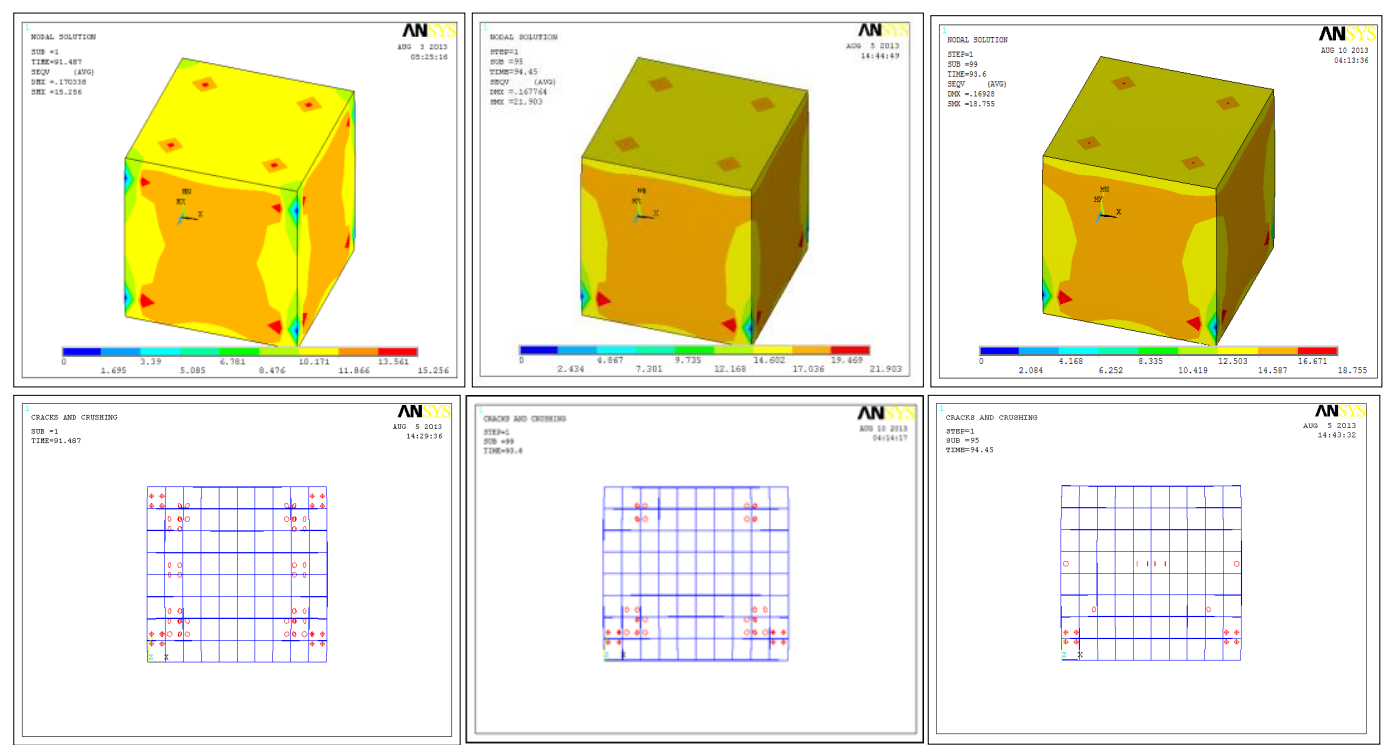

Gambar 8. Gambar Tegangan Von Misess dan Pola Retak Benda Uji Kubus Dimensi $200 \mathrm{~mm} \times 200 \mathrm{~mm}$ yang Terkekang , $\mathrm{s}=50 \mathrm{~mm}$

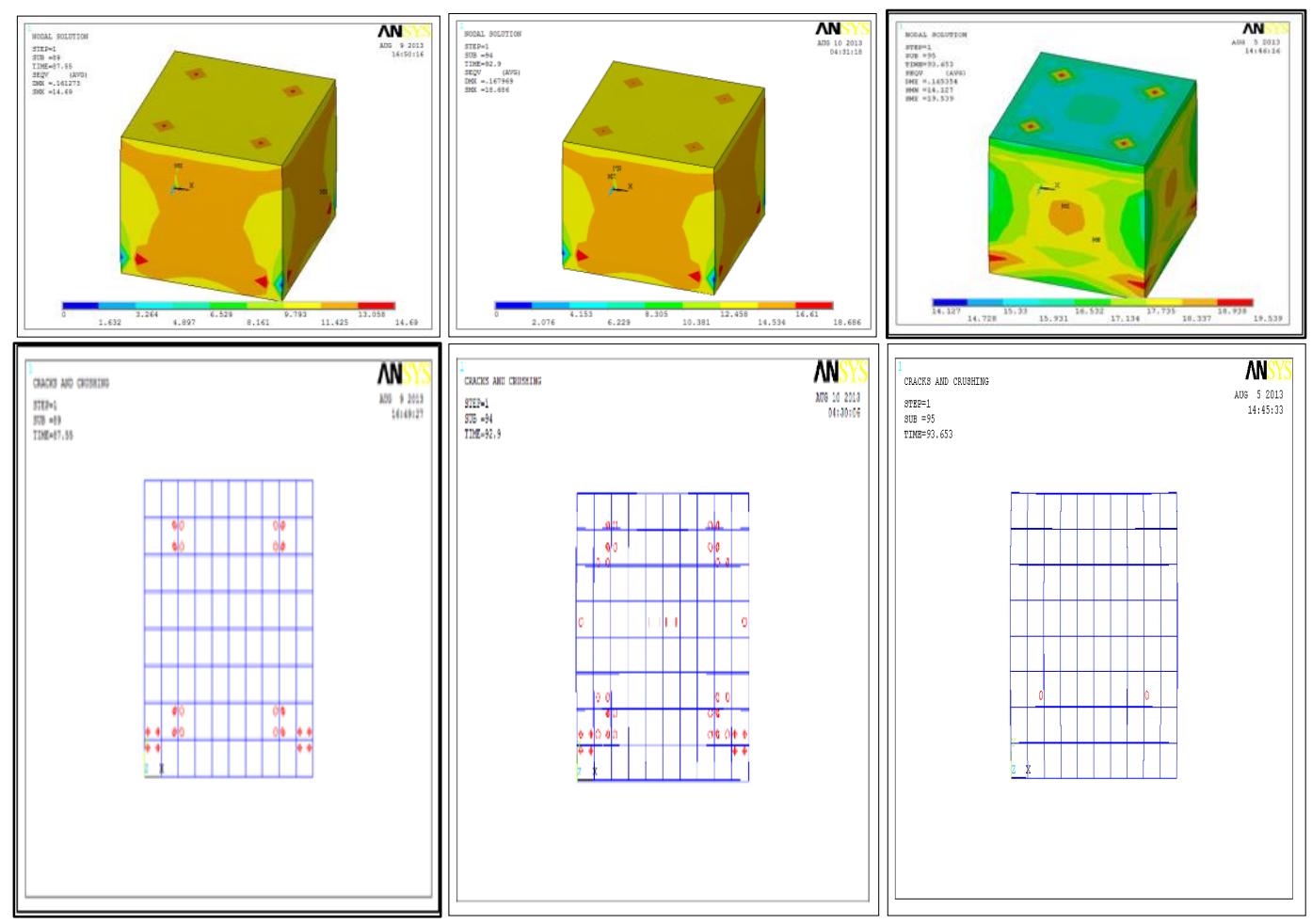

Gambar 9. Gambar Tegangan Von Misess dan Pola Retak Benda Uji Kubus Dimensi $200 \mathrm{~mm} \times 200 \mathrm{~mm}$ yang Terkekang, $\mathrm{s}=100 \mathrm{~mm}$ 
Pada Gambar 10 tegangan maksimum dan keretakan terjadi di daerah tengah silinder. Kenaikan mutu beton sejajar dengan kenaikan tegangan maksimum yang terjadi

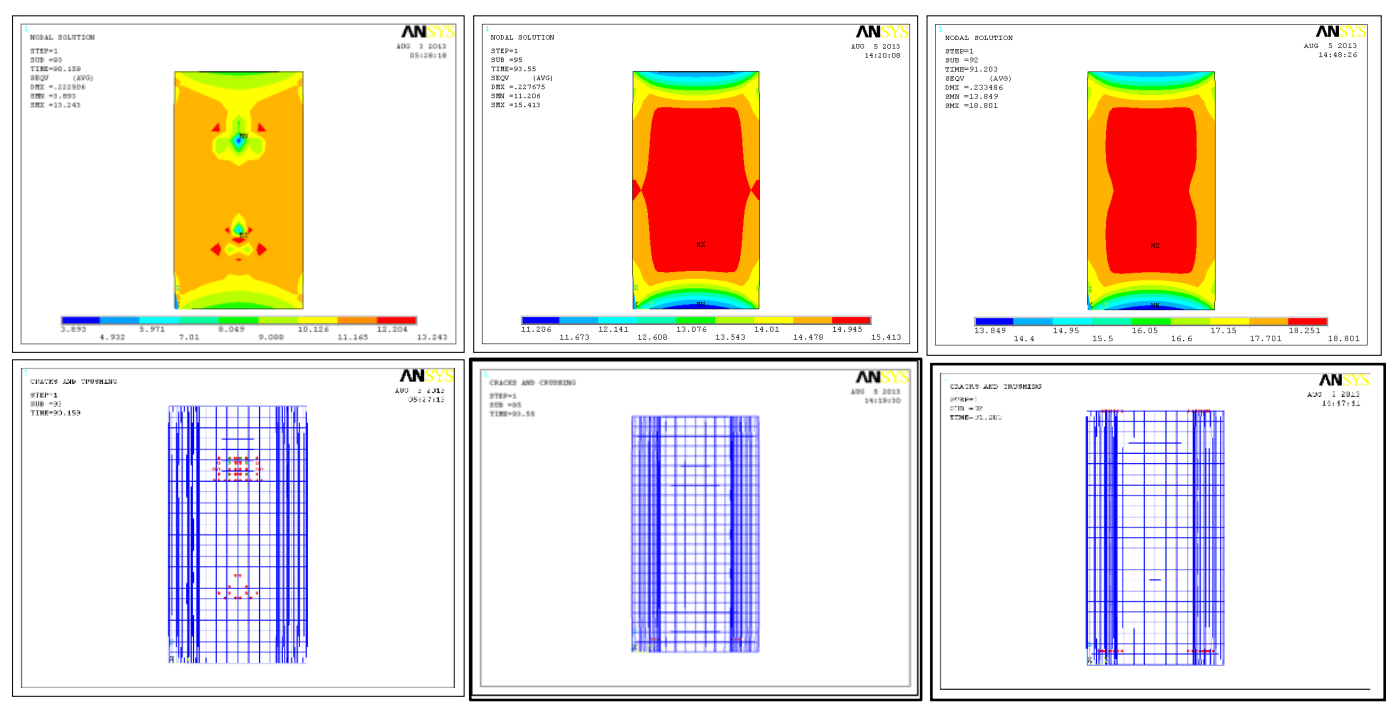

Gambar 10. Gambar Tegangan Von Misess dan Pola Retak Benda Uji Silinder Diameter $150 \mathrm{~mm}$ dan tinggi $300 \mathrm{~mm}$ Tak Terkekang

Pada Gambar 11, 12 dan 13 tegangan maksimum dan keretakan terjadi di daerah sekitar sengkang atas dan bawah silinder. Kenaikan mutu beton sejajar dengan kenaikan tegangan maksimum yang terjadi
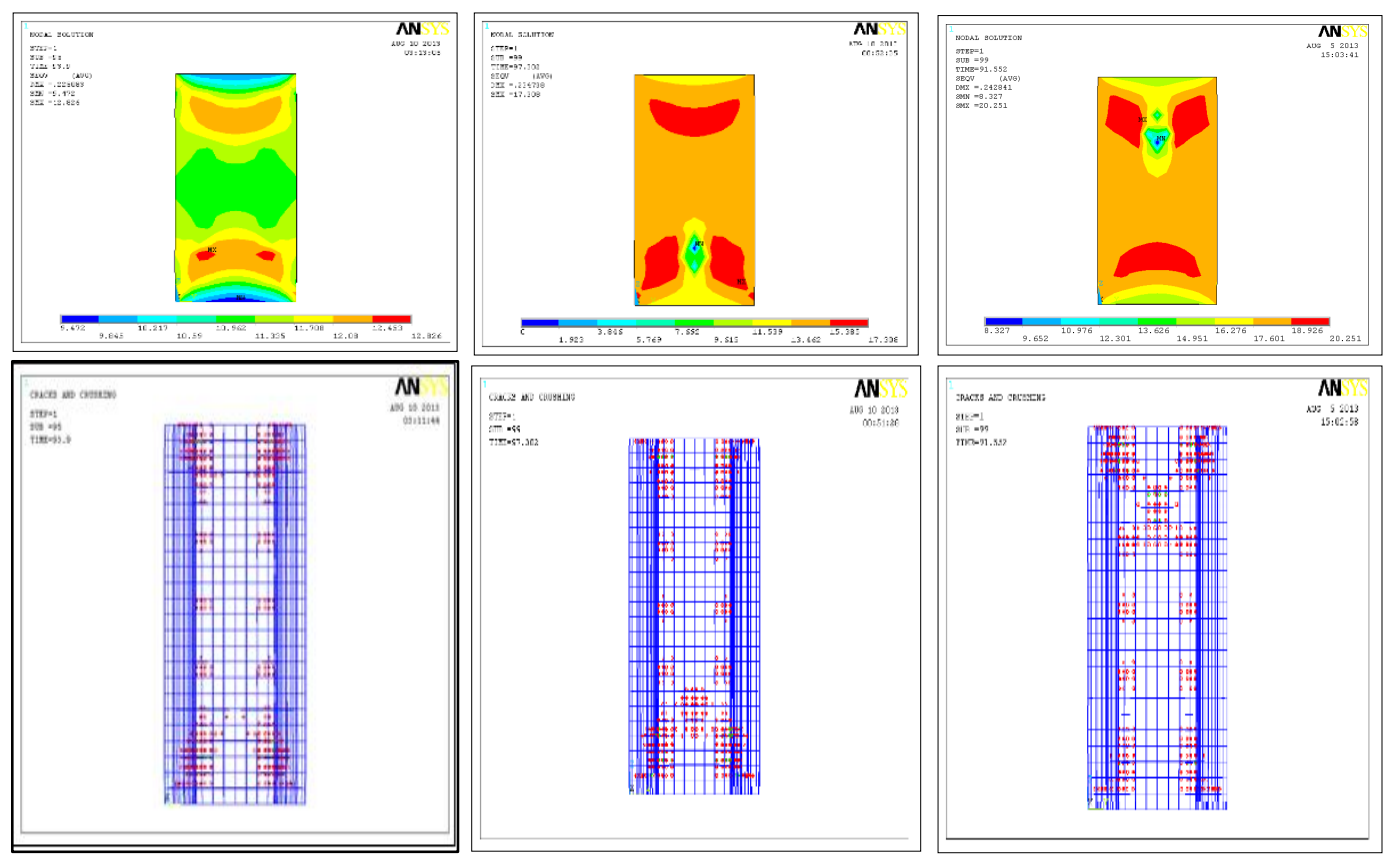

Gambar 11. Gambar Tegangan Von Misess dan Pola Retak Benda Uji Silinder Diameter $150 \mathrm{~mm}$ dan tinggi $300 \mathrm{~mm}$ yang Terkekang, $\mathrm{s}=50 \mathrm{~mm}$ 


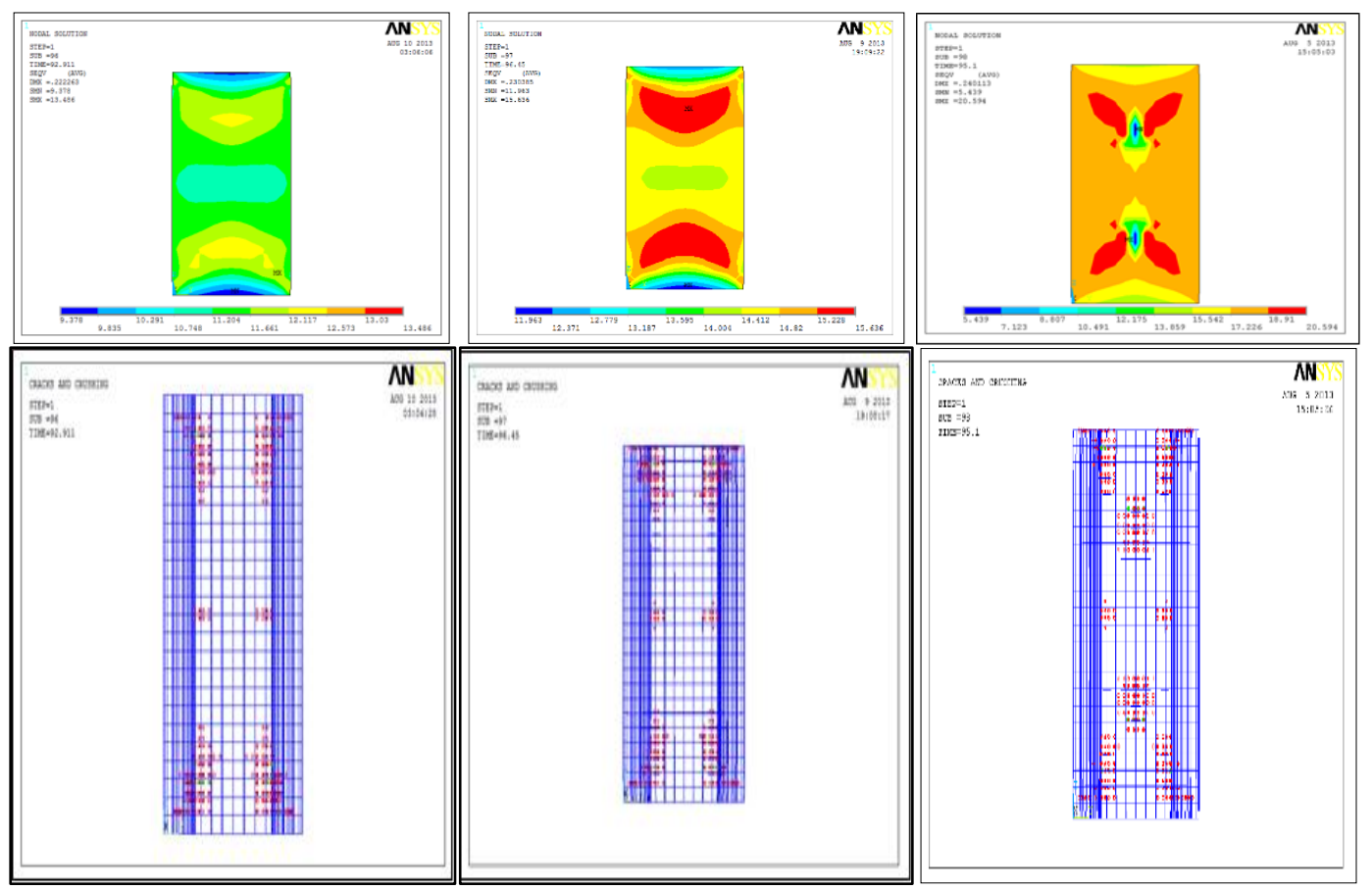

Gambar 12. Gambar Tegangan Von Misess dan Pola Retak Benda Uji Silinder Diameter $150 \mathrm{~mm}$ dan tinggi $300 \mathrm{~mm}$ yang Terkekang, $\mathrm{s}=100 \mathrm{~mm}$

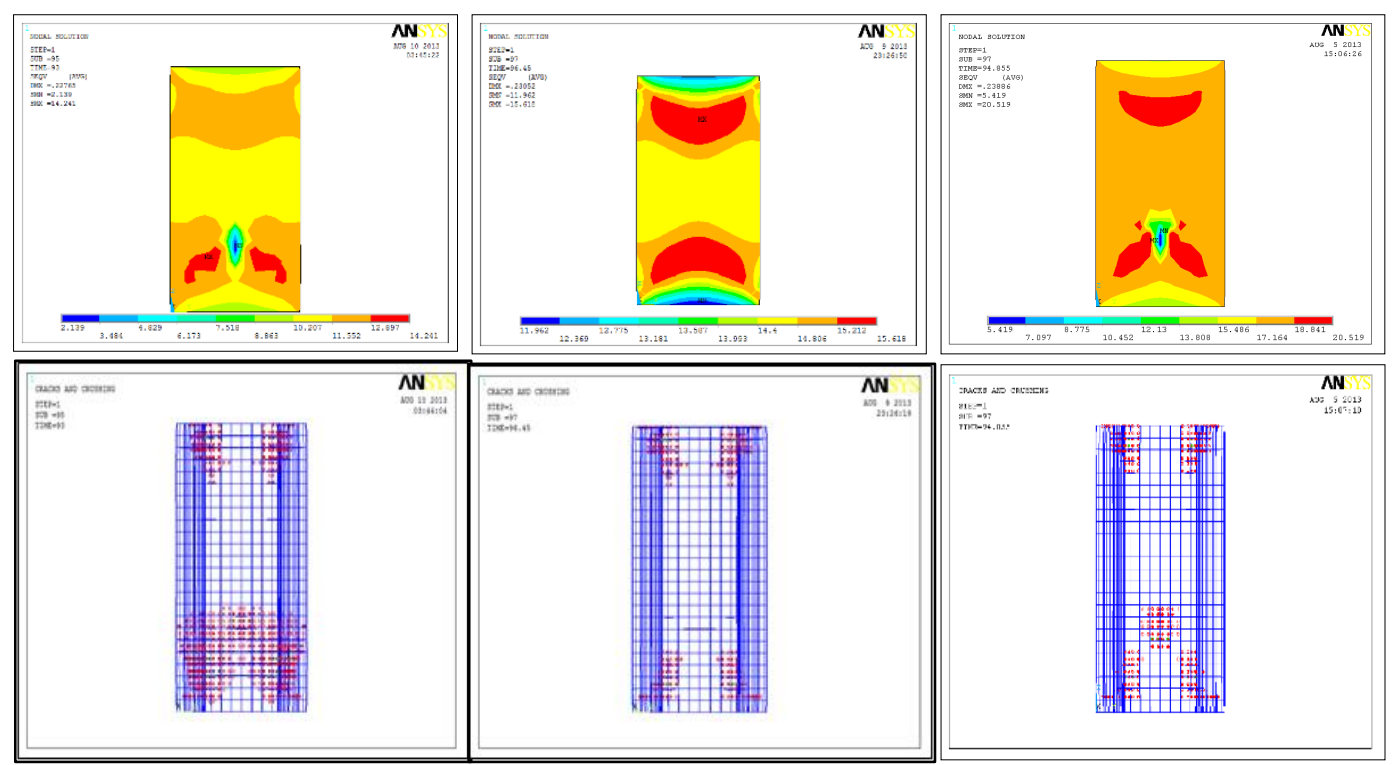

Gambar 13. Gambar Tegangan Von Misess dan Pola Retak Benda Uji Silinder diameter $150 \mathrm{~mm}$ dan tinggi $300 \mathrm{~mm}$ yang terkekang, $\mathrm{s}=200 \mathrm{~mm}$

Berdasarkan hasil analisis yang dilakukan terhadap model kubus dan silinder terhadap perilaku pola retak yang terjadi dengan variasi mutu beton dan pengekangan dapat disimpulkan sebagai berikut:

1. Perilaku keruntuhan tekan yang terjadi pada model dipengaruhi oleh pengekangan dan mutu dari material beton. Perilaku nilai tegangan dan regangan yang terjadi dipengaruhi oleh mutu material beton dan pengekangan, yaitu 
a. Semakin tinggi mutu beton maka nilai tegangan maksimum yang dicapai juga semakin besar, sedangkan nilai regangannya semakin kecil.

b. Untuk model bentuk silinder tak terkekang dengan $f_{c}^{\prime}, 20 \mathrm{MPa}$ nilai tegangan maksimumnya adalah $11,72 \mathrm{MPa}$ nilai regangan maksimumnya adalah 0,017 .

c. Untuk $f_{c}$ ' $25 \mathrm{MPa}$ nilai tegangan maksimumnya mengalami kenaikan sebesar $27,73 \%$, nilai regangan maksimumnya terjadi penurunan sebesar $21,43 \%$ terhadap model silinder $f_{c}$ '20 MPa.

d. Dan $f_{c}$ ' $30 \mathrm{MPa}$ nilai tegangan maksimumnya mengalami kenaikan sebesar $63,39 \%$, nilai regangan maksimumnya terjadi penurunan sebesar $54,54 \%$ terhadap model silinder $f_{c}$, $20 \mathrm{MPa}$.

e. Model yang terkekang nilai tegangan maksimumnya lebih besar daripada yang tak terkekang, sedangkan nilai regangannya semakin kecil.

f. Untuk model bentuk silinder yang terkekang dengan jarak sengkang $50 \mathrm{~mm}$, $f_{c}$ ' $20 \mathrm{MPa}$ nilai tegangan maksimumnya adalah $13,15 \mathrm{MPa}$ nilai regangan maksimumnya adalah 0,016 .

g. Untuk $f_{c}$ ' $25 \mathrm{MPa}$ nilai tegangan maksimumnya terjadi kenaikan sebesar $25,78 \%$, nilai regangan maksimumnya terjadi penurunan sebesar $23,07 \%$ terhadap model silinder $f_{c}^{\prime} 20 \mathrm{MPa}$.

h. Dan $f_{c}$ ' $30 \mathrm{MPa}$ nilai tegangan maksimumnya terjadi kenaikan sebesar $53,15 \%$, nilai regangan maksimumnya terjadi penurunan sebesar $45,45 \%$ terhadap model silinder $f_{c}^{\prime} 20 \mathrm{MPa}$.

2. Model yang tak terkekang pola retaknya terlihat lebih sedikit sehingga beton bersifat getas dan terjadi keruntuhan langsung atau tiba-tiba.

3. Pengaruh pengekangan terhadap benda uji kubus dan silinder adalah jarak sengkang model yang mempengaruhi nilai beban maksimum, semakin rapat jarak antar sengkang maka nilai beban maksimum semakin besar, tegangan maksimum juga semakin besar sedangan nilai regangan semakin kecil.

a. Untuk model kubus dimensi $200 \mathrm{~mm} \times 200 \mathrm{~mm} \times 200 \mathrm{~mm}$ mutu beton 20 MPa nilai beban maksimum yang dicapai pada model FEA adalah 119,60 $\mathrm{kN}$ tanpa pengekangan.

b. Dengan pengekangan pada jarak sengkang $100 \mathrm{~mm}$ nilai beban maksimum terjadi kenaikan sebesar 170, 09\% terhadap model tanpa pengekangan.

c. Dengan pengekangan pada jarak sengkang $50 \mathrm{~mm}$ nilai beban maksimum terjadi kenaikan sebesar 359, 82\% terhadap model tanpa pengekangan.

d. Sedangkan untuk model silinder diameter $150 \mathrm{~mm}$ tinggi $300 \mathrm{~mm}$ beban maksimum yang dicapai pada model FEA adalah 43,63 kN tanpa pengekangan.

e. Dengan pengekangan pada jarak sengkang $200 \mathrm{~mm}$ beban maksimum terjadi kenaikan sebesar 53,02\% terhadap model tanpa pengekangan.

f. Dengan pengekangan pada jarak sengkang $100 \mathrm{~mm}$ beban maksimum terjadi kenaikan sebesar $87,03 \%$ terhadap model tanpa pengekangan.

g. Dengan pengekangan pada jarak sengkang $50 \mathrm{~mm}$ beban maksimum yang terjadi kenaikan sebesar 353,40\% terhadap model tanpa pengekangan.

4. Model bentuk kubus $150 \mathrm{~mm} \times 150 \mathrm{~mm}$ yang terkekang dengan jarak pengekangan $50 \mathrm{~mm}$ pola retaknya terlihat di daerah sekitar sengkang. 
5. Model bentuk kubus $200 \mathrm{~mm} \times 200 \mathrm{~mm}$ yang terkekang dengan jarak pengekangan $50 \mathrm{~mm}$ dan $100 \mathrm{~mm}$ pola retaknya terlihat di daerah sekitar sengkang dan karena kenaikan mutu beton pola retaknya semakin berkurang.

6. Model silinder yang terkekang dengan jarak pengekangan $50 \mathrm{~mm}$ pola

7. retaknya terlihat di daerah sekitar sengkang dan atas silinder sehingga keruntuhan yang terjadi adalah keruntuhan karena beton silinder bersifat overreinforced.

8. Model silinder yang terkekang dengan jarak pengekangan $200 \mathrm{~mm}$ pola retaknya terlihat di daerah sekitar sengkang dan bawah silinder sehingga keruntuhan yang terjadi adalah keruntuhan karena beton silinder bersifat underreinforced.

\section{Kesimpulan}

\section{PENUTUP}

Berdasarkan hasil analisis yang dilakukan terhadap model kubus dan silinder terhadap perilaku tegangan von misses dan pola keretakan yang terjadi dengan variasi mutu beton dan pengekangan dapat disimpulkan sebagai berikut:

1. Perilaku perilaku tegangan von misses dan pola keretakan yang terjadi dipengaruhi oleh mutu dari material baja untuk tulangan dan material beton. Semakin tinggi mutu beton maka nilai tegangan maksimum yang dicapai juga semakin besar.

2. Jarak sengkang model mempengaruhi nilai beban maksimumnya, semakin rapat jarak antar sengkang maka nilai beban maksimum semakin besar.

3. Luas pembebanan dari bentuk model mempengaruhi nilai beban maksimum yang dapat ditahan oleh model tersebut, semakin tinggi nilai luasan pembebanan maka ketahanan beton terhadap pembebanan juga semakin tinggi.

\section{DAFTAR PUSTAKA}

1. Abisetyo, Windunoto. 2009. Studi Pengaruh Pengekangan pada Balok Beton Bertulangan Rangkap dengan Unified Theory. Institut Teknologi Sepuluh Nopember. Surabaya.

2. ANSYS. 1999. ANSYS User's Manual Revision 5.6, ANSYS, Inc., Canonsburg, Pennsylvania.

3. ASTM C39-94. 1996. Test Method for Compressive Strength of Cylindrical Concrete Specimens. ASTM Standards: Concrete and Aggregates, V.04.02., Philadelphia

4. Dipohusodo, Istimawan. 1994. Struktur Beton Bertulang. Jakarta. Gramedia Pustaka Utama.

5. Nawy, Edward G. 1998. Beton Bertulang Suatu Pendekatan Dasar. Bandung. PT. Refika Aditama.

6. Park, R. dan T. Paulay. 1975. Reinforced Concrete Structures. John Willey \& Sons. New York, US.

7. Ridzeki, Fitriani. 2020. Perbandingan Kuat Tekan Beton yang Terkekang pada Benda Uji Kubus dan Silinder. Makalah Disajikan dalam Seminar Nasional Teknik. Universitas Islam Kalimantan, Banjarmasin, 24 Oktober 2020.

8. Tjitradi, Darmansyah. 2018. Visualisasi dan Analisis Keruntuhan Balok Beton Bertulang Menggunakan ANSYS. Jurnal Gradasi Teknik Sipil. Volume 2 No 1. 